\title{
Influence of Portfolio Management in Decision-Making
}

\author{
Rolney Baptestone ${ }^{1}$ iD, Roque Rabechini $\mathrm{Jr}^{1,2}$ iD \\ ${ }^{1}$ Universidade Nove de Julho (Brazil) \\ ${ }^{2} E S A N-$ Graduate School Business (Peru) \\ rolney.caio@gmail.com,roque@rabechini.com.br
}

Received: October 2017

Accepted: March 2018

\section{Abstract:}

Purpose: This research aims to demonstrate how portfolio management influences the decision-making process of the best projects for the company.

Design/methodology/approach: In order to reach this goal, the single case study method was used. Initially, it was made a bibliometric with "portfolio management" subject followed by the term "decision-making". Thus, it was possible to do an analysis about the relationships between the themes.

Findings: One of the findings of this research was the migration of the portfolio management process vision, from project controls tools to a process that aims at a strong alignment with the strategic management of the organization. This is an important point to academic implication.

Research limitations/implications: The main academic implications of this research were to show how it is possible to construct a model about the relations between project portfolio management and decision-making.

Practical implications: Regarding the practical implications, it was verified the importance of the analysis of the portfolio for decision-making, to the detriment of the evaluation of only one project.

Social implications: Thus, the companies can now concentrate its efforts in the analysis of profitability and return on investment of the projects, assisting the whole process of decision-making.

Originality/value: The portfolio management influences the decision-making process.

Keywords: portfolio management, project management, strategic management, decision-making

\section{Introduction}

Portfolio management has its origin in the 1950s, having started in the financial sector, but it was from the 1990s that the theme became more explored. The concept of the portfolio is addressed in different sectors: financial, products, among others, but in this research the subject of portfolio management focused on projects was addressed. It is a dynamic decision-making process in which projects are constantly updated and revised. It covers a series of decision-making in project management, including periodic portfolio reviews of all projects, to define the allocation of strategic resources (Cooper, Edgett \& Kleinschmidt, 1999).

With the intention of minimising risks and increasing the chances of success, some organisations, as suggested by Carvalho, Lopes and Marzagão (2013), use portfolio management models in line with company strategy. In addition, the authors emphasise the need to analyse the portfolio management process not only as a simple management tool due to its complexity. 
According to Cooper, Edgett and Kleinschmidt (2001), in the portfolio management process, projects are evaluated and selected, and can be accelerated or canceled. Resources are allocated consistently amongst portfolio projects and can be reallocated in a timely manner in active projects. The portfolio management decision process is characterised by uncertainties, constant changes, dynamic opportunities, multiple objectives and strategic considerations, as well as interdependencies between projects.

Portfolio management has become a significant factor in the success of organisations long-term strategies and is related to the role of senior executives and key decision makers who must validate relevant investments and formulate and program goals and objectives (Archer \& Ghasemzadeh, 1999; Cooper et al., 2001).

Other aspects that challenge both executives and academics in relation to decision-making are financial crisis, competitiveness and globalisation, as there are evident impacts on risk during decision-making, as well as the need of Decision-making processes that will lead to the best results, even with scarce resources (Façanha \& Yu, 2011; Torres Jr. \& Moura, 2011).

The effectiveness of a decision, however, is linked to the processes used in choosing the best option (Dean Jr. \& Sharfman, 1996), which can be characterised through learning and establishing cause and effect relationships of the respective options, resulting in the improvement of success. This success in the company, in the long term, depends on effective decision-making processes related to the opportunities available in the project portfolio (Cooper et al., 1999; Chao \& Kavadias, 2008).

Success expressed in satisfaction with fairies, results of good decisions and related subjectivity was an element established by Bernoulli (1954) in the configuration of the theory of utility. Based on this concept, Dean Jr. and Sharfman (1996) established that a decision can only be considered effective if it is characterised by its consolidation in the form of action and by the attainment of its objectives as planned.

Given the context presented, this research aims to demonstrate how portfolio management influences the decisionmaking process in the projects of a financial organisation. As previously pointed out, the literature suggests that there are few studies in the research and proposal of practices aimed at integrating sustainability in project portfolio management, especially in portfolio decision-making (Brones, Carvalho \& Zancul, 2014; Khalili-Damghani \& Tavana, 2014; Silvius \& Schipper, 2014). There are regular calls in the literature for the development of portfolio management processes for decision-making (Cooper et al., 1999, 2004a, 2004b; Hauser, Tellis \& Griffin, 2006), since the existing literature has provided little understanding of how decisions are made (Kester, Griffin, Hultink \& Lauche, 2011).

In order to understand the relationship between portfolio management and decision-making, the following research question was formulated - and has guided this study: How does portfolio management influence decision-making within the projects of a financial organisation?

This research is organised as follows: The introduction described the contextualisation in which the study is inserted, indicating the researches developed regarding the studied subject, as well as the importance of the present work, the research question and its objective. The literature review brings the theoretical foundation, conceptualising the axes, portfolio management and decision-making, and the research methodology presents the proposal of the single case study and the methodological procedures that will guide the collection and analysis of data. The analysis and interpretation of the results will be presented in the discussion, together with the academic and practical contributions, and the conclusion of the work shows its limitations and indications for future studies.

\section{Literature Review}

\subsection{Portfolio Management}

The survey on the subject was defined in a research front of the last 20 years to account for the authors' work in order to trace trends in a particular field of study, according to Mostafa (2002). It was analysed the theme of project portfolio management and evaluated whether there is obsolescence of the literature on the subject, verifying if it was highlighted some classic in the literature of portfolio management in projects between the years of 1994 and 2015. 
This research analysed the results of two studies (Carvalho et al., 2013; Baptestone \& Rabechini Jr., 2016), which have used some research criteria to retrieve articles. As a consequence, the time interval from 1994 to 2015 was delimited.

In the study by Carvalho et al. (2013), the selection criteria for the articles in the sample was the combination of the keywords "Portfolio Management" and "Project Management" in the summary, using the ISI Web of Knowledge database (between 1994 and 2010) and Scielo database (between 2003 and 2010). Figure 1 shows the workflow with 96 articles, which resulted in the initial search of 86 articles in the ISI Web of Knowledge database (between 1994 and 2010), of which eight $(9 \%)$ were excluded due to the fact that they were related to the portfolio of investments. In the Scielo database (between 2003 and 2010), there was an initial search for 10 articles, three of them (30\%) were excluded, since they were more focused on investment portfolio, therefore, they did not fit into the theme of this, which resulted in a final sample of 85 papers.

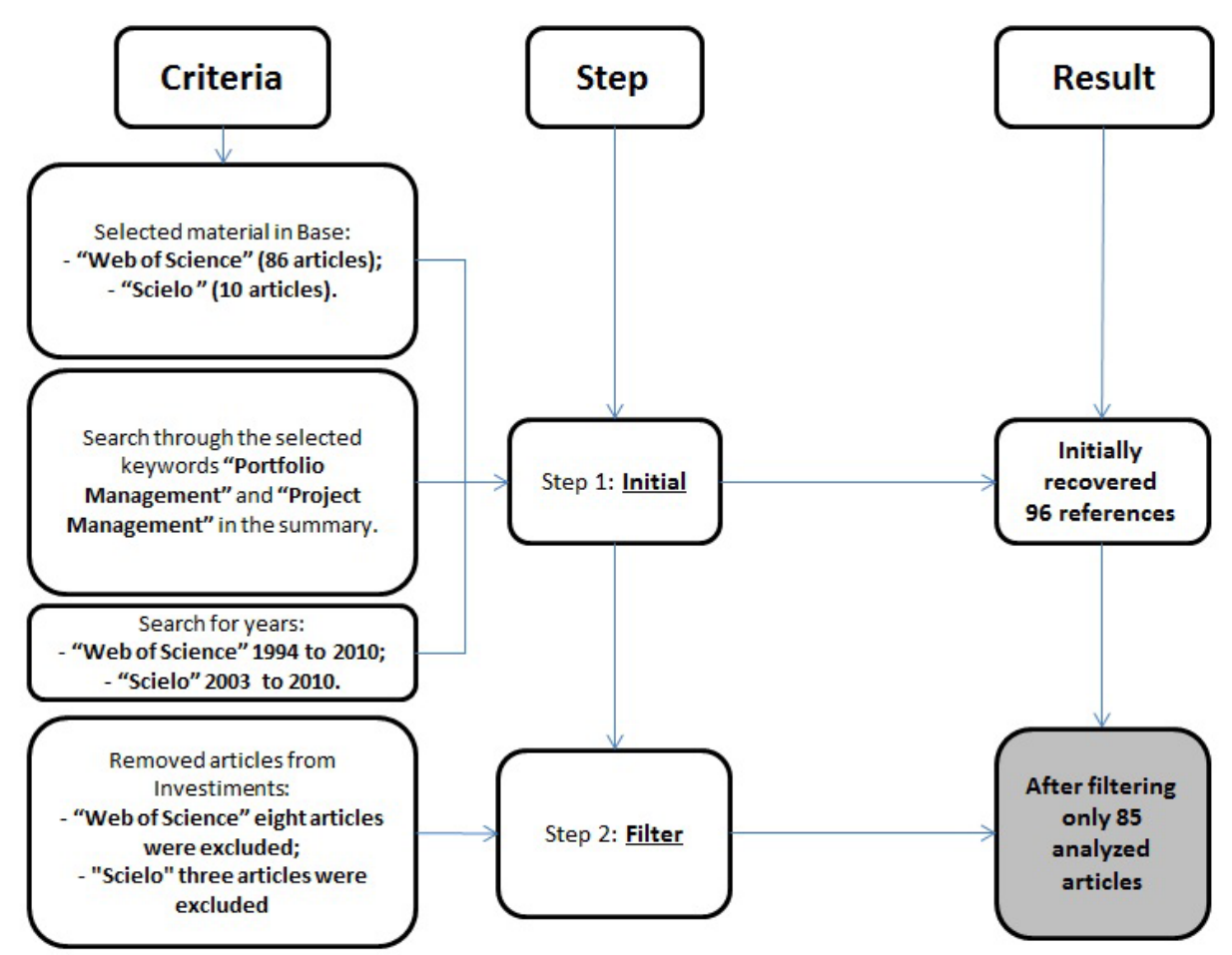

Figure 1. Phases of bibliomtric research between 1994 and 2010 (based on Carvalho et al., 2013)

In the evaluation of the most cited articles between the years of 1994 and 2015, different citation analysis criteria were used between the two studies. Between 1994 and 2010, according to Table 1, groups of papers that were cited more than 10 times were used as a cut-off criterion and, based on that, the list of 20 cited articles was obtained. A comparison was made between the number of citations, according to the research by Carvalho et al. (2013) and the number of citations in April 2016, for that, based on Google Scholar.

In agreement with the research by Baptestone and Rabechini Jr. (2016), between the years of 2010 and 2015 , due to the short time, all the mentioned articles were considered; and, based on this criterion, the list of 22 cited articles was obtained, as described in Table 2.

It is noteworthy that, in relation to the most cited articles (above 10 citations), $47.24 \%$ are concentrated in the first four periodicals of the year 2012, proving the concentration of articles in that year. Based on the relevance of the theme portfolio management, these studies describe the main articles and authors related to the topic studied. The distribution of the articles will be presented per year, since 1994, according to Figure 3. 


\begin{tabular}{|c|c|c|c|c|c|}
\hline Article & $\begin{array}{l}\text { Total Citations, } \\
\text { Carvalho et al. } \\
\text { (2013) }\end{array}$ & $\begin{array}{l}\text { Total Citations } \\
\text { (Google } \\
\text { Academico- } \\
\text { Abr } / 16)\end{array}$ & $\begin{array}{l}\% \text { in relation } \\
\text { to Total } \\
1994 \text { a } 2010\end{array}$ & $\begin{array}{c}\text { Cumulative } \\
\% \\
1994 \text { a } 2010\end{array}$ & $\begin{array}{l}\text { Cumulative } \\
\% \text { \% } \\
1994 \text { a } 2015\end{array}$ \\
\hline $\begin{array}{l}\text { Cooper, Edgett \& Kleinschmidt } \\
\text { (1999) }\end{array}$ & $87\left(1^{\circ}\right.$ more cited $)$ & 645 & 16.46 & 16.46 & 15.94 \\
\hline $\begin{array}{l}\text { Cooper, Edgett \& Kleinschmidt } \\
\text { (2000) }\end{array}$ & 14 & 340 & 8.68 & 25.13 & 24.35 \\
\hline $\begin{array}{l}\text { Cooper, Edgett \& Kleinschmidt } \\
\text { (2004) }\end{array}$ & $29\left(3^{\circ}\right.$ more cited $)$ & 304 & 7.76 & 32.89 & 31.86 \\
\hline $\begin{array}{l}\text { Dickinson, Thornton \& Graves } \\
\text { (2001) }\end{array}$ & 28 ( $4^{\circ}$ more cited $)$ & 281 & 7.17 & 40.06 & 38.80 \\
\hline Wang \& Hwang (2007) & 34 (2o more cited $)$ & 264 & 6.74 & 46.80 & 45.33 \\
\hline Hart, Jan Hultink \& Tzokas (2003) & 27 & 250 & 6.38 & 53.18 & 51.51 \\
\hline $\begin{array}{l}\text { Cooper, Edgett \& Kleinschmidt } \\
(2002)\end{array}$ & 10 & 239 & 6.10 & 59.28 & 57.41 \\
\hline Mikkola (2001) & 19 & 227 & 5.79 & 65.07 & 63.03 \\
\hline $\begin{array}{l}\text { Bardhan, Bagchi \& Sougstad } \\
\text { (2004) }\end{array}$ & 22 & 205 & 5.23 & 70.30 & 68.09 \\
\hline $\begin{array}{l}\text { Blau, Pekny, Varma \& Bunch } \\
\text { (2004) }\end{array}$ & 27 & 172 & 4.39 & 74.69 & 72.34 \\
\hline $\begin{array}{l}\text { Coldrick, Longhurst, Ivey \& } \\
\text { Hannis (2005) }\end{array}$ & 20 & 145 & 3.70 & 78.39 & 75.93 \\
\hline Lin \& Hsied (2004) & 19 & 138 & 3.52 & 81.91 & 79.34 \\
\hline Girotra, Terwiesch \& Ulrich (2007) & 12 & 127 & 3.24 & 85.15 & 82.48 \\
\hline Lint \& Pennings (2001) & 10 & 112 & 2.86 & 88.01 & 85.24 \\
\hline Cooper \& Edgett (2003) & 13 & 107 & 2.73 & 90.74 & 87.89 \\
\hline Gustafsson \& Salo (2005) & 12 & 102 & 2.60 & 93.34 & 90.41 \\
\hline Rogers, Gupta \& Maranas (2002) & 23 & 97 & 2.48 & 95.82 & 92.81 \\
\hline $\begin{array}{l}\text { Mojsilović, Ray, Lawrence \& } \\
\text { Takriti (2007) }\end{array}$ & 10 & 60 & 1.53 & 97.35 & 94.29 \\
\hline Siddiqi (2000) & 22 & 60 & 1.53 & 98.88 & 95.77 \\
\hline Miller (2005) & 11 & 44 & 1.12 & 100.00 & 96.86 \\
\hline General Total & 271 & 3919 & & & \\
\hline
\end{tabular}

Table 1. Most cited works between 1994 and 2010 (in the survey by Baptestone and Rabechini Jr. (2016), after searching for the key words in the ISI Web of Knowledge database between 2011 and 2015, 81 references were found, and it has been decided that only academic articles would be analysed, due to the peer evaluation process and because they contained the necessary information for bibliometric analysis. Thus, a total of 39 articles were retrieved for further analysis, as shown in Figure 2) 


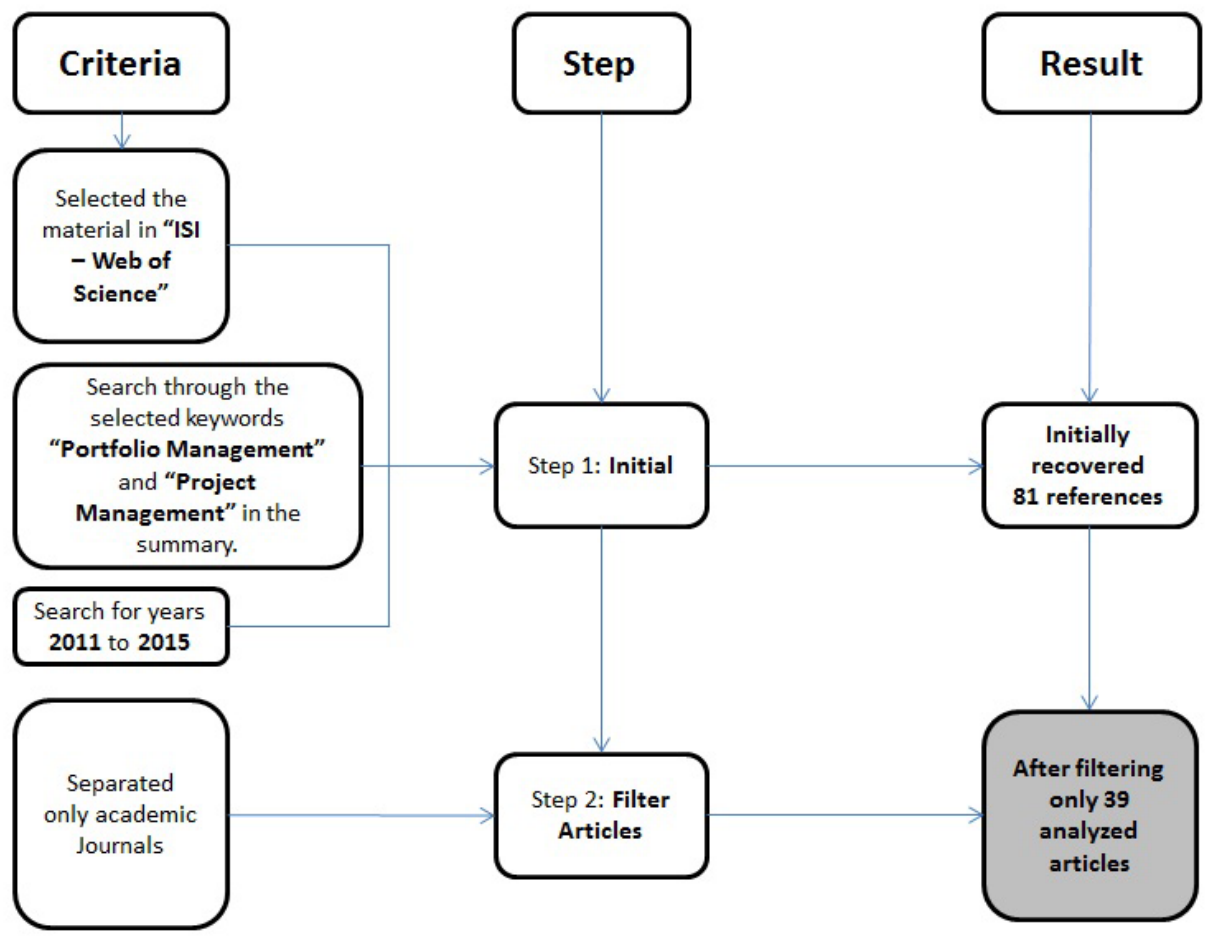

Figure 2. Phases of bibliometrc research between 2011 and 2015 (Baptestone \& Rabechini Jr., 2016)

\begin{tabular}{|c|c|c|c|c|}
\hline Article & $\begin{array}{c}\text { Total Citations, } \\
\text { Baptestone } \& \\
\text { Rabechini Jr. (2016) }\end{array}$ & $\begin{array}{c}\% \text { in relation } \\
\text { to Total } \\
2011 \text { a } 2015\end{array}$ & $\begin{array}{l}\text { Cumulative \% } \\
2011 \text { a } 2015\end{array}$ & $\begin{array}{l}\text { Cumulative \% } \\
1994 \text { a } 2015\end{array}$ \\
\hline Teller, Unger, Kock \& Gemünden (2012) & 20 & 15.75 & 15.75 & 97.36 \\
\hline Killen, Jugdev, Drouin \& Petit (2012) & 14 & 11.02 & 26.77 & 97.70 \\
\hline Unger, Gemünden \&Aubry (2012) & 14 & 11.02 & 37.80 & 98.05 \\
\hline Heising (2012) & 12 & 9.45 & 47.24 & 98.34 \\
\hline Katzy, Turgut, Holzmann \& Sailer (2013) & 9 & 7.09 & 54.33 & 98.57 \\
\hline Yaghootkar \& Gil (2012) & 8 & 6.30 & 60.63 & 98.76 \\
\hline Jonas, Kock \& Gemünden (2013) & 7 & 5.51 & 66.14 & 98.94 \\
\hline Young, Young, Jordan \& O’Connor (2012) & 6 & 4.72 & 70.87 & 99.09 \\
\hline Verma, Mishra \& Sinha (2011) & 5 & 3.94 & 74.80 & 99.21 \\
\hline Gleadle, Hodgson \& Storey (2012) & 4 & 3.15 & 77.95 & 99.31 \\
\hline Morris \& Geraldi (2011) & 4 & 3.15 & 81.10 & 99.41 \\
\hline Patanakul (2013) & 4 & 3.15 & 84.25 & 99.51 \\
\hline Hall (2012) & 3 & 2.36 & 86.61 & 99.58 \\
\hline Johansson, Hicks, Larsson \& Bertoni (2011) & 3 & 2.36 & 88.98 & 99.65 \\
\hline Too \& Weaver (2014) & 3 & 2.36 & 91.34 & 99.73 \\
\hline Haji-Kazemi, Andersen \& Krane (2013) & 2 & 1.57 & 92.91 & 99.78 \\
\hline Kim, Kim, Lee, Kwon \& Lee (2011) & 2 & 1.57 & 94.49 & 99.83 \\
\hline Nascimento (2013) & 2 & 1.57 & 96.06 & 99.88 \\
\hline Spalek (2014) & 2 & 1.57 & 97.64 & 99.93 \\
\hline
\end{tabular}




\begin{tabular}{|c|c|c|c|c|}
\hline Article & $\begin{array}{c}\text { Total Citations, } \\
\text { Baptestone \& } \\
\text { Rabechini Jr. (2016) }\end{array}$ & $\begin{array}{l}\% \text { in relation } \\
\text { to Total } \\
2011 \text { a } 2015\end{array}$ & $\begin{array}{l}\text { Cumulative \% } \\
2011 \text { a } 2015\end{array}$ & $\begin{array}{l}\text { Cumulative \% } \\
1994 \text { a } 2015\end{array}$ \\
\hline $\begin{array}{l}\text { Rijke, van Herk, Zevenbergen, Ashley, } \\
\text { Hertogh \& ten Heuvelhof (2014) }\end{array}$ & 1 & 0.79 & 98.43 & 99.95 \\
\hline Serra \& Kunc (2015) & 1 & 0.79 & 99.21 & 99.98 \\
\hline Zeynalzadeh \& Ghajari (2011) & 1 & 0.79 & 100.00 & 100.00 \\
\hline General Total & 127 & & & \\
\hline
\end{tabular}

Table 2. Most cited works between the years of 2011 and 2015 (based on research by Baptestone \& Rabechini Jr., 2016)

\section{Articles by Year}

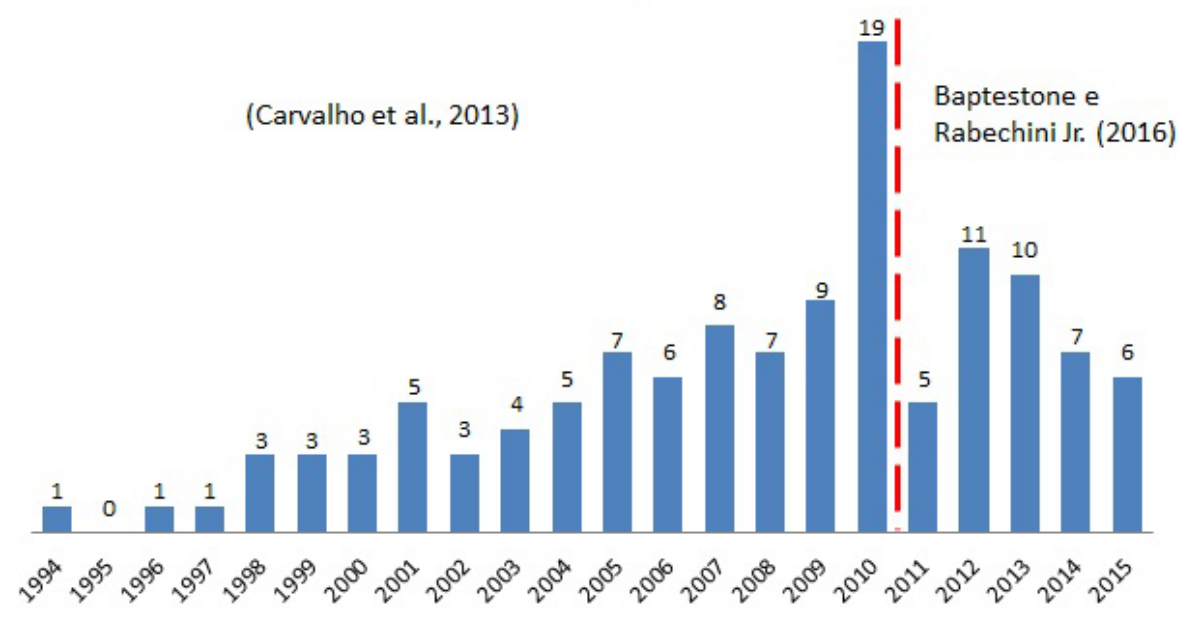

Figure 3. Articles with the key "Portfolio Management" and "Project Management" between 1994 and 2015

Regarding the study of the articles, the theme portfolio management presented few citations until 2002, registering a growth from 2004, with a peak in 2010, indicating a growing area of knowledge (Carvalho et al., 2013). The research reveals a drop in the publication of articles in 2011, year when the research by Baptestone and Rabechini Jr. (2016) began, with a significant increase in 2012, with the concentration of the most important articles related to the second research; and finalising the study in 2015, returning to the level of publications of the year 2006, which might mean a possible drop in interest in the subject of portfolio management.

Concerning the index of centrality of the keyword network, a comparison of the centrality index was carried out in the research by Baptestone and Rabechini Jr. (2016) and, according to Table 3, it was verified that, in the survey of articles between the years of 1994 and 2010, the key word "Strategy" was in seventh place and the degree of centrality was used to identify the four areas most closely related to the portfolio theme: 1) A1 - Performance; 2) A2 - Product Development; 3) A3 - Research and Development; and 4) A4 - Risk and Uncertainty. In the survey carried out with articles between the years of 2011 and 2015, the keyword number one was "Strategy Implementation", increasingly proving portfolio management linked to company strategy.

However, according to Baptestone and Rabechini Jr. (2016), it is also important to highlight the importance of Portfolio Management as an important selection tool for project management in organizsations. This fact has been confirmed, since the word "Selection" appears in the 11th place in the survey of articles between 1994 and 2010, and in the 12th place in the index of centrality between 2011 and 2015. 


\begin{tabular}{|c|c|c|c|c|}
\hline $\begin{array}{l}\text { Keyword } 1994 \text { a } 2010 \\
\text { (Sitkis-version } 2.0 \text { and Graphic Ucinet } \\
\text { 6-version 6.289) - Full Article }\end{array}$ & $\begin{array}{l}\text { Centrality } \\
\text { Index }\end{array}$ & $\begin{array}{c}\text { Keyword } 2011 \text { a } 2015 \\
\text { (UCINET 6.587) - Title and } \\
\text { Summary }\end{array}$ & $\begin{array}{l}\text { Centrality } \\
\text { Index }\end{array}$ & $\begin{array}{l}\text { Normalized } \\
\text { input level }\end{array}$ \\
\hline Portfolio Management & 54,000 & $\begin{array}{l}\text { Strategy implementation (Main } \\
\text { focus between } 2010 \text { and 2015) }\end{array}$ & 34,000 & $73.90 \%$ \\
\hline Product Development (A2) & 41,000 & Previous research & 28,000 & $60.90 \%$ \\
\hline Management & 31,000 & Multiple project & 21,000 & $45.70 \%$ \\
\hline Performance (A1) & 29,000 & Strategic management theory & 20,000 & $43.50 \%$ \\
\hline Lessons & 19,000 & Improvement & 19,000 & $41.30 \%$ \\
\hline Leaders & 19,000 & Evaluation & 17,000 & $37.00 \%$ \\
\hline Strategy (Trend between 1994 and 2010) & 18,000 & Relationship & 15,000 & $32.60 \%$ \\
\hline Framework & 17,000 & Issue & 15,000 & $32.60 \%$ \\
\hline Project Selection & 15,000 & Process model & 14,000 & $30.40 \%$ \\
\hline Innovation & 15,000 & Project selection & 14,000 & $30.40 \%$ \\
\hline Selection (Common) & 14,000 & Smes & 13,000 & $28.30 \%$ \\
\hline Uncertainty (A4) & 13,00 & Selection (common) & 12,000 & $26.10 \%$ \\
\hline Research and development (A3) & 12,000 & Ppmo & 12,000 & $26.10 \%$ \\
\hline Project Manager & 11,000 & Technological innovation & 11,000 & $23.90 \%$ \\
\hline Model & 11,000 & Term & 11,000 & $23.90 \%$ \\
\hline Project Portfolio Management & 8,000 & Complexity & 10,000 & $21.70 \%$ \\
\hline Valuation & 6,000 & Interdepedency & 10,000 & $21.70 \%$ \\
\hline Decision Analysis & 5,000 & Business strategy & 10,000 & $21.70 \%$ \\
\hline
\end{tabular}

Table 3. Comparison of the Centrality Index between articles from 1994 to 2000 and 2011 to 2015 in the keyword network

According to Modica, Braun and Rabechini Jr. (2010), portfolio management is presented as a complex discipline because it ranges from the strategic level of the organisation to the departments responsible for the ongoing projects, thus requiring communication, both top-down and bottom-up, as well as dealing with issues of a political nature within the organisation, such as the allocation of resources and the prioritisation of some projects to the detriment of others, which requires the ability to negotiate with stakeholders.

Based on Siqueira and Crispim (2014), one of the biggest challenges for organisations is to develop and improve the ability to compose a portfolio of projects that is aligned with the business model and that contributes to achieving the results and benefits expected by the organisation. For this reason, Engwall and Jerbrant (2003) reinforce the need for comparative studies amongst the different project contexts within the portfolio, since they understand that there is little knowledge about what portfolio management factors are specific to a context and which are universal. In this environment within the portfolio, several projects consume resources from the same source in a highly political context, with a constant competition for priority, people, attention and resources.

In this context, it is necessary to understand the decision-making process and the influence of portfolio management on it.

\subsection{Decision-making}

According to Ginsberg (1988), strategic decisions are the responsibility of managers. They reflect the interaction of an organisation and its environment and show how an organisation manages that relationship. Decisions may be formal or informal and may be related to preestablished or emerging issues (Pennings, 1985). They are incorporated both in the internal context (structural, cultural and political of the company) and in the external context of the organisation (competitive factors) (Pettigrew, 1992). Strategic decisions address concerns that are essential to the 
organisation's livelihood and survival, and often involve a large proportion of the organisation's resources (Elbanna, 2006).

In this decision-making environment, while many organizations ignore or do not have adequate formal decisionmaking processes (Highsmith, 2009), other organisations have a formalised decision-making process, however, this formalisation is not always beneficial, especially in scenarios with radical innovations, formalisation can have negative effects, creating barriers to innovation and reducing opportunities for creativity (Bonner, Ruekert \& Walker, 2002; Sethi \& Iqbal, 2008; Mirow, 2010).

Wilson (2003) points out that strategic decision-making is difficult to define or evaluate in terms of performance, is associated with different compromise and risk solutions, is interrelated to other decisions within the organisation and can set precedence for future decisions, can involve a political decision, involves a high level of uncertainty, rarely is there a better solution and, once a decision is made, it is difficult to reverse it.

Table 4 demonstrates the eight elements, based on Hammond, Keeney and Raiffa (2004), and its relationship with the literature, for the composition of aspects related to decision-making in this work. Being used the elements: objective and consequences, for the decision-making and was detailed in the proposal of the study.

\begin{tabular}{|c|c|c|c|}
\hline $\begin{array}{l}\text { Theory of Decision-making } \\
\text { by Hammond et al. (2004) is } \\
\text { composed of } 8 \text { elements }\end{array}$ & Clemen \& Reilly (1996) & $\begin{array}{l}\text { Russo \& Schoemaker } \\
\text { (2002) }\end{array}$ & $\begin{array}{c}\text { Bazerman \& Moore } \\
\text { (2009) }\end{array}$ \\
\hline Problem & $\begin{array}{l}\text { Decompose and model the } \\
\text { structure of the problem }\end{array}$ & - & Define the problem \\
\hline Goal & $\begin{array}{l}\text { Identify the situation and } \\
\text { understand the goals }\end{array}$ & Framework & - \\
\hline Alternatives & $\begin{array}{c}\text { Identify alternatives; } \\
\text { Choose the best alternative. }\end{array}$ & - & $\begin{array}{l}\text { Identify the criteria; } \\
\text { Generate alternatives. }\end{array}$ \\
\hline Consequences & $\begin{array}{l}\text { Assess whether further analysis is } \\
\text { needed }\end{array}$ & Learning from experience & Weigh the criteria \\
\hline Negotiation & Perform a sensitivity analysis & Meeting of intelligences & $\begin{array}{l}\text { Evaluate each } \\
\text { alternative }\end{array}$ \\
\hline Uncertainty & - & - & - \\
\hline Risk Tolerance & - & - & - \\
\hline Interconnected Decisions & Implement the chosen alternative & Conclusion & $\begin{array}{l}\text { Calculate the optimal } \\
\text { decision }\end{array}$ \\
\hline
\end{tabular}

Table 4. Constructs and concepts of rationality (Elbanna, 2006: page 4)

Several researchers have discussed different dimensions of the strategic decision-making literature. One of the dimensions, described by Papadakis and Barwise (1997), is related to rationality in decision-making processes, occupying a prominent place in strategic decisions in the theoretical and practical spheres. In addition to rational procedures, Butler (2002) also emphasised how executives make decisions using political processes and intuitions.

Political behaviour amongst decision makers has also been recognised as an important aspect of decision-making (Wilson, 2003). Decision-making by intuition is increasingly considered as an important approach to the subject (Miller \& Ireland, 2005). Eisenhardt and Zbaracki (1992) emphasise that the study of intuitions is a way of creating a more realistic view of the strategic decision-making process.

\subsection{Proposition}

Table 5 shows the search variables associated with authors and themes, Portfolio Management (PMP) and Decision-Making (DM). Each variable received a number, its relation to the corresponding theme and the name of 
the variable, which are directly linked to the main contributions of the authors associated with each variable. These variables will be used in the conceptual model of the research in the next chapter.

The variables related to the themes will be the basis for the generation of the conceptual model and the propositions of this research, as well as the methodology adopted to verify the relationship between portfolio management and decision making.

The model is composed of two theoretical axes, portfolio management and decision-making. It was evaluated who makes the decision during the decision-making process in relation to portfolio projects. Through the conceptual model proposed in Figure 4, it was possible to verify, through the propositions, if the main objective of this research, to understand if the portfolio management can influence the decision making process in the projects of an organization.

From the research carried out in this study, proposals were formulated that served as a basis for the elaboration of the interview script that was used as a tool for data collection in the field.

Proposition 1: The use of the process of identifying projects influences the objective of decision-making.

Dean Jr. and Sharfman (1996) have established that a decision can only be considered effective if it is characterised by its consolidation in the form of action and by the attainment of its objectives according to plan. However, the lack of management process and lack of project information have been highlighted as a central barrier to the success of project portfolio (Cooper et al., 2001). So Heising (2012) points out that only effective project management is no longer enough. And portfolio management becomes increasingly important for long-term success and competitive advantage.

Based on what has been presented, generally the use of the process of project identification promotes and can generate better decisions, as it helps in the definition of the problem for which a decision is required, and present in a systemic way the objectives to be achieved through the decision.

Proposition 2: The use of criteria for project selection influences the consequences of decision-making.

Danesh, Ryan and Abbasi (2015), state that in order to execute portfolio management effectively, managers in organisations must map out their projects, and justify their priority against all other projects within the organisation. On the other hand, the model developed by Wang and Hwang (2007) contributed to the selection of project portfolios inserted into a scenario of absence or insufficiency of reliable information to minimise the risks.

Therefore, in this proposal we evaluated the use of project selection criteria and possible alternatives, which are the various courses of action that can be chosen to achieve the objectives, and their respective consequences, since each of the alternatives can have different consequences in achieving the objectives.

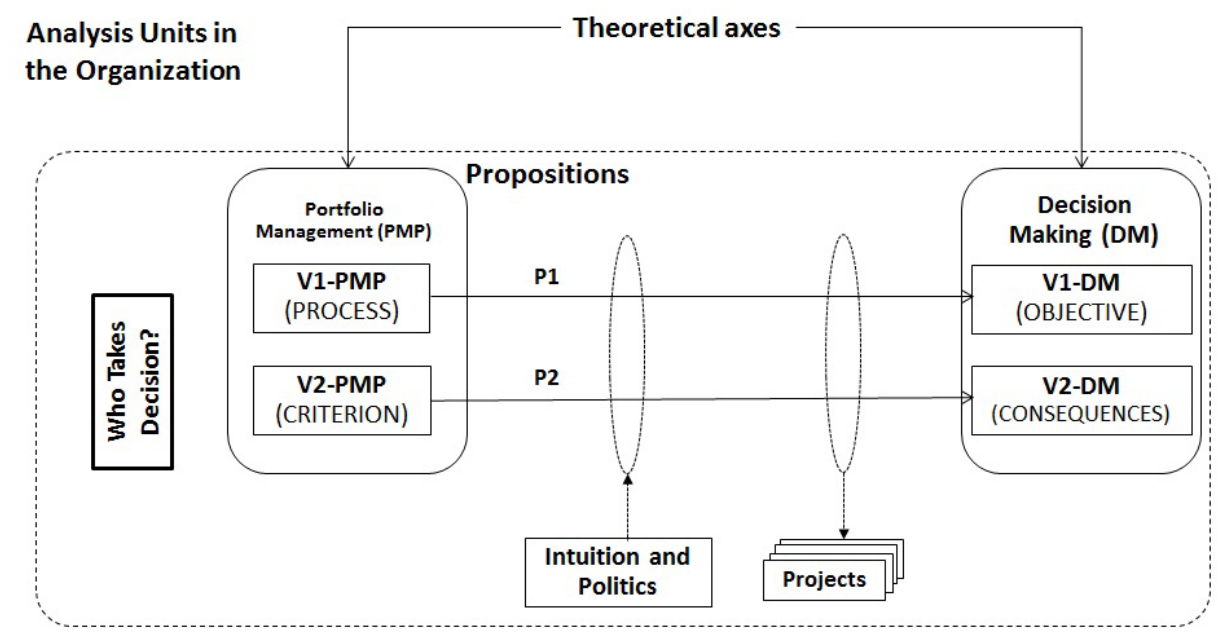

Figure 4. Conceptual Model of the Case Study 
Proposals 1 and 2 will also be evaluated, the politics and the intuition in the decision-making, taking into account that the interaction of interests, conflict and power means that the strategic decision-making process can be characterised as political (Wilson, 2003). That intuition is a synthetic psychological function insofar as one learns the whole of a specific situation, it is often associated with a hunch or a strong sense of knowing what is going to occur (Vaughan, 1989), and is presented as a component of decisions.

\begin{tabular}{|c|c|c|c|}
\hline Theme & Authors & Main contributions & Variable \\
\hline \multirow{8}{*}{$\begin{array}{l}\text { Portfolio } \\
\text { Management } \\
(\text { PMP) }\end{array}$} & Mikkola (2001) & $\begin{array}{l}\text { He argued about the importance of portfolio management as a } \\
\text { strategic tool for the company's positioning in terms of growth } \\
\text { and sustainability of results. }\end{array}$ & \multirow{4}{*}{ V1-PMP - Process } \\
\hline & $\begin{array}{l}\text { Teller, Unger, } \\
\text { Kock \& } \\
\text { Gendered } \\
(2012)\end{array}$ & $\begin{array}{l}\text { It examines that project portfolio management can only operate if } \\
\text { project information is available through formal procedures and } \\
\text { rules to improve the availability of information, thus facilitating } \\
\text { the comparison between different projects. }\end{array}$ & \\
\hline & $\begin{array}{l}\text { Cooper, Edgett } \\
\text { \& Kleinschmidt } \\
\text { (2001a) }\end{array}$ & $\begin{array}{l}\text { Focused portfolio management for product development through } \\
\text { a portfolio decision process that encompasses a range of in- } \\
\text { company decision-making processes, including periodic revisions } \\
\text { of the project portfolio. }\end{array}$ & \\
\hline & Heising (2012). & $\begin{array}{l}\text { It points out that only effective project management is no longer } \\
\text { enough. And that Portfolio management becomes increasingly } \\
\text { important to achieve success and competitive advantage in the } \\
\text { long run. }\end{array}$ & \\
\hline & $\begin{array}{l}\text { Cooper, Edgett } \\
\text { \& Kleinschmidt } \\
(2002)\end{array}$ & $\begin{array}{l}\text { They identified that companies with best portfolio management } \\
\text { practices use the "Stage-Gates" model (decision-making gates in } \\
\text { the portfolio management process). }\end{array}$ & \multirow{4}{*}{$\begin{array}{l}\text { V2-PMP - Criteria } \\
\text { for selecting projects }\end{array}$} \\
\hline & $\begin{array}{l}\text { Coldrick, } \\
\text { Longhurst, Ivey } \\
\text { \& Hannis } \\
(2005)\end{array}$ & $\begin{array}{l}\text { They identified, as a benefit of the use of the selection model, the } \\
\text { formal decision structure and communication of information } \\
\text { about projects. }\end{array}$ & \\
\hline & $\begin{array}{l}\text { Wang \& } \\
\text { Hwang (2007) }\end{array}$ & $\begin{array}{l}\text { It contributed to the selection of project portfolios within a } \\
\text { scenario of lack or insufficiency of reliable information for risk } \\
\text { minimization. }\end{array}$ & \\
\hline & $\begin{array}{l}\text { Danesh, Ryan } \\
\text { \& Abbasi } \\
(2015)\end{array}$ & $\begin{array}{l}\text { Discusses the options for improving decision making in } \\
\text { organizational portfolio management results using hierarchy } \\
\text { analysis processes (AHP). }\end{array}$ & \\
\hline \multirow{5}{*}{$\begin{array}{l}\text { Decision } \\
\text { Making } \\
(\mathrm{DM})\end{array}$} & $\begin{array}{l}\text { Dean \& } \\
\text { Sharfman } \\
(1996)\end{array}$ & $\begin{array}{l}\text { The process of obtaining information relevant to the decision and } \\
\text { its dependencies. And the analysis of this information to make the } \\
\text { choice. }\end{array}$ & \multirow{3}{*}{ V1-DM - Goal } \\
\hline & Elbanna (2006) & How are strategic decisions made? & \\
\hline & $\begin{array}{l}\text { Kester, Griffin, } \\
\text { Hultink \& } \\
\text { Lauche (2011) }\end{array}$ & $\begin{array}{l}\text { Understand how companies manage the portfolio for new product } \\
\text { development and what challenges companies face in making } \\
\text { decisions during the project selection process. }\end{array}$ & \\
\hline & $\begin{array}{l}\text { Pettigrew } \\
(1973)\end{array}$ & Explore issues of power and conflict in organizational life. & \multirow{2}{*}{$\begin{array}{l}\text { V2-DM - } \\
\text { Consequences }\end{array}$} \\
\hline & Pfeffer (1981) & $\begin{array}{l}\text { Study the influence on the results of the decisions, so that the } \\
\text { interests themselves are served, through political techniques. }\end{array}$ & \\
\hline
\end{tabular}

Table 5. Theoretical review 


\section{Methods}

It will be a qualitative and exploratory research that will be characterised by a single case study and that will aim to demonstrate how the portfolio management can influence the decision-making process in the projects of an organization.

The main theoretical axis of this research is portfolio management. Therefore, the first step of this research was to carry out a bibliometric study of the subject between the years of 1994 and 2015. After analysing the data, we noticed a trend of migration with regard to the portfolio management theme, as a tool to support the choice and follow-up on projects, for a support base for strategic management within organisations. The theme decision-making was highlighted as one of the points of support for strategic management, so it was chosen as the other theoretical axis of this research.

The company to be researched is a national private company, from the services sector and based in São Paulo, with open capital, with 230 employees, acting in the banking, retail, industry and services markets. These characteristics justify the analysis, since, despite being a national company, the main shareholder is a company with foreign capital, and there are integration projects between the two companies. The specific study is justified because it is possible to observe the complexity of the decision-making process for the projects in the company studied due to the influence of the main investor on the members of the company object of this study. Due to the analysis of several players in decision-making, from product teams, finance, governance, project managers and IT teams, and this indepth review aims to verify the different views during the decision-making process.

For the reliability of the information collected, the respondents were selected based on the following criteria: 1) to have contact with the portfolio management of the whole company and the decision-making; 2) to have the positions of director, manager, specialist or senior analyst; and 3) to have more than one year of contact experience with portfolio management. Thus, based on the established criteria, 12 professionals from the company were interviewed, to the single case study. The choice of the participants that were interviewed was not for convenience, but based on individual capacity and diversification amongst the areas and positions, so that the information can be captured through different points of view within the company, from the areas of IT and products (operational), passing through the areas of PMO and project managers (tactical and operational), reaching the areas of finance, accounting and new business (strategic). This course will allow us to broaden the research vision for data analysis out.

The methodology used for the analysis and interpretation of the data obtained in this case study was the analysis of qualitative data through five phases of analysis and their interpretations, according to Figure 5, based on Yin (2016). Initially, all interview material was transcribed, later analysed on a case-by-case basis with the questionnaires, and the extra annotations and organisational information served as a complement. The entire content of the interviews was organized into initial categories (Initial Code - Level 1) established with the aid of software (Excel) for analyses and textual statistics. Subsequently, it was performed and interpreted in a consolidated way, together with the bibliographic review, and the results obtained were organised and described in new categories (Category Code - Level 2) grouped by analogy.

The procedures for data analysis were: 1) listening and transcription of interviews; 2) research of company information on the main forms of work of the organisation; 3) data analysis and interpretation, according to Figure 5; 4) joint and consolidated analysis of the results obtained in parallel with the bibliographical review carried out; and 5) preparation of the final text of the analyses and interpretations of the results and final considerations.

For the analysis and interpretation of data, the compilation was the organisation of the data collected. In the process of data decomposition, the data coding process was used through the "Initial Codes (Level 1)", and the items that appeared to be essentially similar received the same code. The nature of the initial codes may be called level 1 codes or open codes, these codes may stick closely to the original items, including reusing the exact words of the original item (Yin, 2016). As the coding of the first level was advanced, it was assessed how the level 1 codes were related to each other, and the next step was to move progressively to an even higher conceptual level, 
recognising the categories in which the level 1 could be framed. In this way the coding proceeds to a second set of higher level codes through the "Category Code (Level 2)", which can be called level 2 or category.

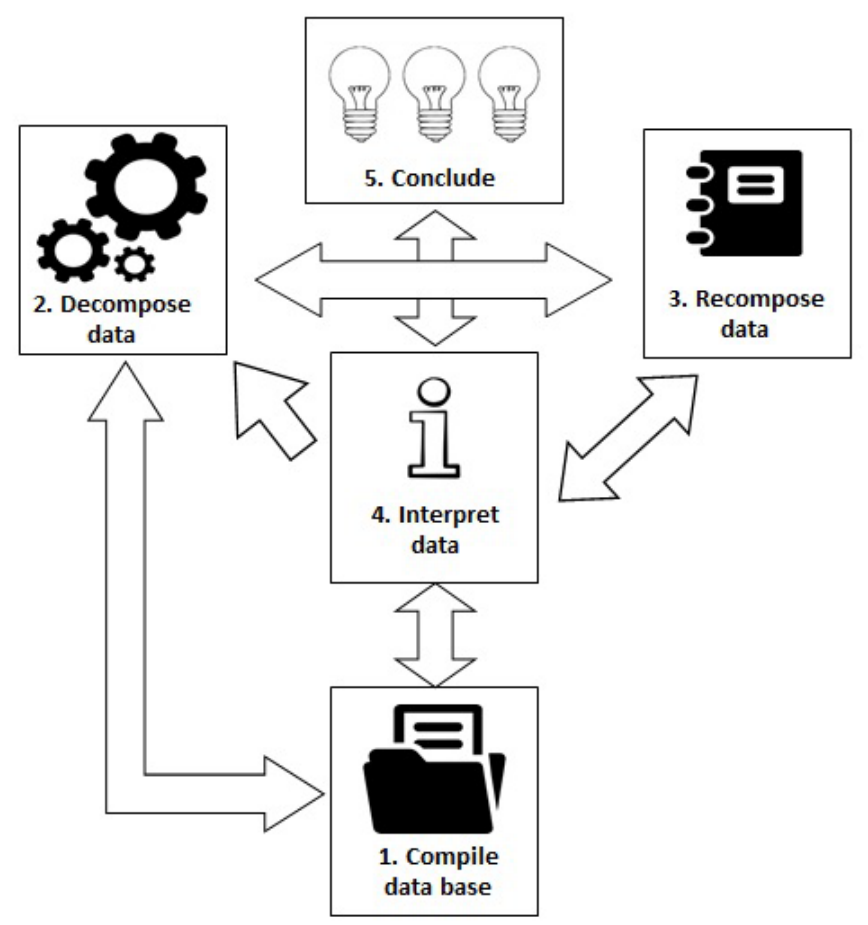

Figure 5. Five phases of analysis and their interactions (based on Yin, 2016)

According to Yin (2016), recomposition will consist in taking the codes to an even higher conceptual level, in which themes, or even concepts, begin to emerge. After the recomposition, through arrangements, the broader and more essential themes will be presented, preparing the interpretation and the conclusion.

\section{Discussion}

After compiling the information from the answers to the questions, we will evaluate below through the data decomposition process the main results obtained for each question and its relationship with the portfolio management literature and decision-making.

Regarding proposition 1, which evaluates "the use of the process of identifying projects influences the objective of decision-making", in the analysis of the question: "During the process of choosing the portfolio projects, what are the main objectives to be achieved with this decision?", it was detected that the strategic objective (Category: strategic management) is the main objective to be achieved with decision-making. The authors Cooper et al. (2001) and Kester et al. (2011) corroborate that the transparency of information on the projects of the portfolio form the basis for a good decision-making and facilitate the prioritisation of the projects aligned with the company strategy.

For the analysis of the question: "What information do you need? Where do you get this information from?" It was detected that knowing the project estimates (Category: add value) is necessary for the decision-making, confirming that the steps indicated by Clemen and Reilly (1996: page 6) are important for decision-making, in order to add value to the process: a) identify the situation and understand the objectives; b) identify the alternatives; c) decompose and model the structure of the problem, uncertainty and preferences; d) choose the best alternative; e) perform a sensitivity analysis; f) assess whether further analysis is required; and g) implement the chosen alternative.

In the analysis of the question: "In a decision-making process, how do you handle the most important information in the process of identifying and choosing projects?", the need to evaluate the impact on the business was verified (Category: business impact) to deal with the most important information during the decision-making process, 
because according to Dean Jr. and Sharfman (1996), a decision process, to result in an effective choice, must be: 1) oriented towards the proper accomplishment of the objectives organisations; 2) based on accurate information and linked to various options to achieve the objectives; and 3) based on the appreciation and understanding of environmental constraints.

For the analysis of the question: "What is the most important information for decision-making, when identifying and choosing portfolio projects?", return and return on investment (Category: financial return) are the most important information for the decision-making, and meet the main objectives of the importance of portfolio management, as analysed by Cooper et al. (2001), and are related to maximising return and achieving financial goals.

For the analysis of the question: "How much information do you contribute with to your decision-making (in percentage)? How much of your intuition do you use to make a decision (in percentage)?", it was found that the information is the basis for decision-making in $75.83 \%$ of the cases. However, as Grant (2003) argues, rapid change requires approaches to flexible and creative strategic formulation, and making decisions by intuition is seen as a viable approach in today's business because few strategic decisions have the advantage of being complete, accurate and timely. Thus, managers' intuition was also taken into account in $24.71 \%$ of the cases, and according to Parikh (1994), intuition may be a form of intelligence that decision makers can use when they are not able to access rational processes.

In the question: "During the process of identifying and choosing portfolio projects, do the preferences of the most powerful prevail? Why?", in $91.67 \%$ of the cases, respondents said that "the opinion of the most powerful prevails", and that political behaviour, according to Allison, Aguero-Martinez, Aguado-Barrena, Vargas-Pallares, Cordov de Armas and Garcia (1971) and Pettigrew (1973), was recognised as an important aspect in decisionmaking in organisations.

For the analysis of the question: "During the process of identifying and choosing portfolio projects, are there attempts to influence the outcomes of decision processes to serve one's own interests?", it was found that the opinion of the interviewees is divided. While half of the respondents believe that there are no attempts to influence the outcomes of decision processes to serve their own interests, aiming at improving and continuing business (within the category: adding value), the other half of respondents believe that there are attempts to influence the outcomes of decision processes to serve their own interests, through strategic planning and governance (within the category: strategic management), confirming the two key ideas related to politics in the dimension of decision-making. First, people within organisations have differences of interests as a result of functional, hierarchical, professional and personal factors (Hickson, Butler, Cray, Mallory, \& Wilson, 1986; Pettigrew, 1973). Second, people in organisations try to influence decision-making so that their own interests are served, and they do so by using a variety of political techniques (Bacharach \& Lawler, 1980; Pfeffer, 1981).

In analysing the question: "Do you think the use of project portfolio management techniques and tools helped the decision-making process in your organisation? Why?", in relation to the use of project portfolio management techniques and tools, efficiency (within the category: aggregate value), strategic planning (within the category: strategic management) and return on investment of the category: financial return), are directly linked to the decision-making process. Proving that portfolio management, according to Heising (2012), becomes increasingly important to achieve success and competitive advantage in the long term.

For the analysis of the question: "What are the strengths of how portfolio decisions are being made within the company? What do you think could be improved?", it was found that the strengths are related to strategic planning (within the category: strategic management) and efficiency (within the category: adding value). As for the improvements pointed out, they are related to strategic planning, strategic objective and thinking as a company and not individually (within the category: strategic management), confirming the application of strategic portfolio management theories, according to Killen, Jugdev, Drouin and Petit (2012), in a vision based on human resources, dynamic capacities and absorption, based on the importance of knowledge and learning, aligned with strategic management and its application to project management.

Regarding proposition 2, which evaluates "the use of criteria for project selection that influence the consequences of decision-making", in the analysis of the question: "What types of methods are being used within the company 
for decision-making in the portfolio?", it was found that the most used method in the company for decision-making was the financial method, using financial indices (e.g. net present value and payback), with the opinion of $55 \%$ of respondents, but other methods were also used, making it clear that portfolio management can use different methods.

For the analysis of the question: "What are the consequences, pros and cons of the chosen methods", it shows that in the opinion of $50 \%$ of the interviewed the pros of the most used methods in the company for decision-making is the return on investment (category: financial return). While in the opinion of $50 \%$ of the interviewees the cons of the methods most used in the company for decision-making is "not to contribute to the improvement and continuity of business", failing to add value, and targeting only the projects with financial benefit, leaving important projects, such as: structuring projects, projects aimed at improving the perception of clients, amongst others.

In the analysis of the question: "Which criteria were used to select the projects?", all the criteria indicated in the literature (Allison et al., 1971, Mikkola, 2001) have been confirmed: growth, profitability, customer experience and cost-effectiveness. With the addition of criteria raised during the interviews: mitigation of operational risks, business intelligence, business diversification, audit points and quality.

For the analysis of the question: "Did the use of criteria, as a consequence for portfolio selection of projects, helped in decision-making? Why?", it was found that the use of criteria helps decision-making, through welldefined strategic objectives (in the category: strategic management), and Cooper, Edgett and Kleinschmidt (1997) corroborate that portfolio management models use a lot of information that can overwhelm the executives of the organisations and consequently cannot use them properly. And this demonstrates the need to clearly define the criteria that will be used for decision-making.

Finally, in the analysis of the question: "What is the most important information for choosing a project?", it was verified that the most important information for choosing a project is the return on investment (in the category: financial return).

In the recomposition, two procedures were used to bring the codes to an even higher conceptual level, in which themes, or even concepts, began to emerge. In the first data recomposition procedure, the similarities and dissimilarities between the data items in Table 6 were compared. Category "CA1 - Aggregate Value" was the one that obtained the largest number of similar expressions, in a total of 16 terms of the "Initial Code (Level 1)" and the highest number of occurrences, for a total of 48 occurrences. On the other hand, category "CA5 - Power" showed the lowest expressiveness amongst the categories, with only 1 terms of the "Initial Code (Level 1)", with the same name "Power", with only 3 occurrences. Demonstrating that portfolio management for decision-making is aimed at more "Add Value" than a "Power" relationship during the decision-making process.

The second procedure aims to constantly practice rival thinking, amongst the data available in Table 6, through alternative explanations for initial observations. For this analysis, two categories were evaluated, "CA2 - Strategic Management", with 45 occurrences, and "CA3 - Financial Return", with 30 occurrences, since even though it had less occurrence than the "CA1 - Add Value" category, with 48 occurrences, categories CA2 and CA3 showed a higher concentration than category CA1, so in the portfolio management process for the decision-making the terms "Strategic Objective", with 21 occurrences (category: strategic management), and "Return on Investment", with 21 occurrences (category: financial return), are very relevant factors and should be taken into account during the decision-making process. After the arrangements cited during the recomposition, the broader and more essential themes covered in interpretation and conclusion will be presented.

According to the results obtained in the qualitative evaluation, it was possible to answer the research question about the relation of how portfolio management influences the decision-making within the scope of the projects of a Financial organisation.

This relationship of influence was possible by accepting proposal 1 of the research, with the capacity of portfolio management to influence decision-making, adding value to the business, being aligned with the organisation's strategy, generating financial returns and positive impacts on the business. From the results obtained, it was possible to prove that "the use of project identification process influences the decision-making objective", after validation 
that $82.09 \%$ of respondents' opinion (110 responses out of 134 responses) were related to proposition 1 , concentrated in only four categories: $38,18 \%$ of respondents' opinion (42 responses related to proposition 1, in a total of 48 answers of the term "add value" throughout the research, according to Figure 6), believe that portfolio management influences the decision-making process to add value to the business.

While in the opinion of $31.82 \%$ of respondents (35 responses related to proposition 1, out of a total of 45 answers to the term "strategic management" throughout the research), portfolio management influences the decisionmaking process, 23 responses related to proposition 1, out of a total of 30 responses from the term "financial return" throughout the survey, believe that portfolio management influences the generate financial return.

Disregarding the categories below 20\%, the categories "business impact" and "power" were excluded due to the low representativeness of these categories in the general context, since only $6.36 \%$ of respondents' opinions ( 7 responses related to proposition 1, in a total of 8 responses to the term "impact on the business" throughout the research), believe that portfolio management influences the decision-making process to generate a positive impact on the business, and only 2.73\% (3 occurrences in a total of 3 occurrences in the term) believe that power in portfolio management influences decision-making.

It was also possible to identify strategic management, financial return and the ability to add value as criteria of moderate relevance in the decision-making process, accepting proposition 2, "the use of criteria for project selection influences the consequences of decision". Only these categories showed significant results, after validating that $17.91 \%$ of opinions of respondents (24 responses out of 134 responses with associated categories) were related to proposition 2, concentrated in these three categories: because $41.67 \%$ of the respondents (10 responses related to proposition 2, out of a total of 45 occurrences of the term "strategic management" throughout the research) believe that the use of criteria in project selection influences decision-making to assist in the strategic management of the organisation.

While in the opinion of $29.17 \%$ of respondents $(7$ responses related to proposition 2 , out of a total of 30 occurrences of the term "financial return" throughout the research) the use of criteria in project selection influences decision-making to generate a financial return to the organization, $25 \%$ of the respondents (6 responses related to proposition 2, out of a total of 48 occurrences of the term "aggregate value" throughout the research) believe that the use of criteria in project selection influences decision-making to add value to the organisation. Disregarding the categories: impact on the business with only $4.16 \%$ of respondents' opinion ( 1 answers related to proposition 2 , in a total of 8 occurrences of the term "impact on the business") and power (with no occurrence for proposition 2).

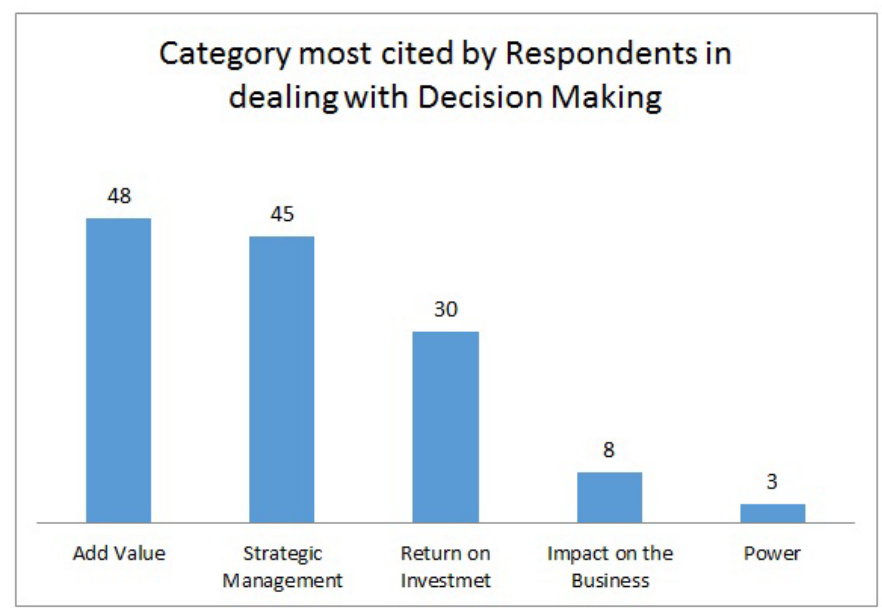

Figure 6. Category most cited by Respondents in dealing with Decision-making 


\begin{tabular}{|c|c|c|c|c|c|}
\hline $\begin{array}{l}\text { Category } \\
\text { Code }\end{array}$ & Category Name & $\begin{array}{l}\text { Initial Code } \\
\text { (Level 1) }\end{array}$ & Initial Code Name & Occurrences & Proposition \\
\hline \multirow{19}{*}{ CA1 } & \multirow{19}{*}{$\begin{array}{l}\text { Add Value (48) } \\
\text { Proposition } 1=43 \\
\text { Proposition } 2=5\end{array}$} & \multirow{2}{*}{ CI 1} & \multirow{2}{*}{ Efficiency (10) } & 9 & P1 \\
\hline & & & & 1 & $\mathrm{P} 2$ \\
\hline & & \multirow{2}{*}{ CI 2} & \multirow{2}{*}{ Ability to meet projects (7) } & 4 & P1 \\
\hline & & & & 3 & $\mathrm{P} 2$ \\
\hline & & \multirow{2}{*}{ CI 3} & \multirow{2}{*}{ Add Value(5) } & 4 & P1 \\
\hline & & & & 1 & P2 \\
\hline & & CI 4 & Know project estimates (5) & 5 & P1 \\
\hline & & CI 5 & Business Continuity and Improvement (5) & 5 & P1 \\
\hline & & CI 6 & Point needs (3) & 3 & P1 \\
\hline & & CI 7 & Generate results (3) & 3 & P1 \\
\hline & & CI 8 & Focus on Customer Experience (2) & 2 & P1 \\
\hline & & CI 9 & Atender as áreas de Negócios (1) & 1 & P1 \\
\hline & & CI 10 & Know what's available in the market (1) & 1 & P1 \\
\hline & & CI 11 & Company's image (1) & 1 & P1 \\
\hline & & CI 12 & Maturity (1) & 1 & P1 \\
\hline & & CI 13 & Constant analyzes (1) & 1 & P1 \\
\hline & & CI 14 & Simplicity (1) & 1 & P1 \\
\hline & & CI 15 & Enjoy opportunities (1) & 1 & P1 \\
\hline & & CI 16 & Agility (1) & 1 & P1 \\
\hline \multirow{7}{*}{ CA2 } & \multirow{7}{*}{$\begin{array}{l}\text { Strategic } \\
\text { management (45) } \\
\text { Proposition } 1=35 \\
\text { Proposition } 2=10\end{array}$} & \multirow{2}{*}{ CI 17} & \multirow{2}{*}{ Strategic Objective (21) } & 14 & P1 \\
\hline & & & & 7 & $\mathrm{P} 2$ \\
\hline & & \multirow{2}{*}{ CI 18} & \multirow{2}{*}{ Strategic planning (18) } & 15 & P1 \\
\hline & & & & 3 & $\mathrm{P} 2$ \\
\hline & & CI 19 & Governance (3) & 3 & P1 \\
\hline & & CI 20 & Think Like Company (2) & 2 & P1 \\
\hline & & CI 21 & Synergy(1) & 1 & P1 \\
\hline \multirow{5}{*}{ CA3 } & \multirow{5}{*}{$\begin{array}{l}\text { Financial returns } \\
\text { (30) } \\
\text { Proposition } 1=23 \\
\text { Proposition } 2=7\end{array}$} & \multirow{2}{*}{ CI 22} & \multirow{2}{*}{ Return on Investment (ROI) (21) } & 15 & P1 \\
\hline & & & & 6 & $\mathrm{P} 2$ \\
\hline & & \multirow{2}{*}{ CI 23} & \multirow{2}{*}{ Profitability (8) } & 7 & P1 \\
\hline & & & & 1 & $\mathrm{P} 2$ \\
\hline & & CI 24 & Cost and benefit (1) & 1 & P1 \\
\hline \multirow{3}{*}{ CA4 } & \multirow{3}{*}{$\begin{array}{l}\text { Impact on the } \\
\text { Business (8) } \\
\text { Proposition } 1=7 \\
\text { Proposition } 2=1\end{array}$} & \multirow{2}{*}{ CI 25} & \multirow{2}{*}{ Impact on the Business (7) } & 6 & P1 \\
\hline & & & & 1 & $\mathrm{P} 2$ \\
\hline & & CI 26 & Business Intuition (1) & 1 & P1 \\
\hline CA5 & $\begin{array}{l}\text { Power (3) } \\
\text { Proposition } 1=3\end{array}$ & CI 27 & Power (3) & 3 & P1 \\
\hline
\end{tabular}

Table 6. Table of data recomposition 


\subsection{Implications}

After the discussions about the results of the research we consider relevant to propose some implications of academic and practical order.

The main academic implications of this research were to show how it is possible to construct a model about the relations between project portfolio management and decision-making. In this sense it is important that new research exploring and deepening some specific points: a) the portfolio transition as a simple project control tool for a process of aiding the organisations strategic planning; and b) the portfolio as a decision-making tool for both the tactical level and the strategic level of organisations.

From the practical point of view, it was possible to verify that the most important information for the stakeholders was the profitability and the return on investment of the projects, they are the most important information for a decision-making, captured in the process of portfolio management.

\section{Conclusion}

The migration of the portfolio management process, from project control tools, to a process that aims at a strong alignment with the strategic management of the organisation was the most important finding of this research.

Analysis of the data collected has shown the relationship between project portfolio management and decision-making. It was possible to verify that the main objective to be achieved during decision-making is to focus on the "strategic objective" of the organisation. It is necessary to "know the project estimates" to add value during decision-making.

It is possible to conclude that the profitability and return on investment, captured in the process of portfolio management, are the most important information for a decision-making process, taking into account that information is the basis for decision-making in $75.83 \%$ of cases, and that intuition can also be used in $24.71 \%$ of cases, when the decision maker does not hold all the information.

Regarding the managers' attempt to influence the results, in the portfolio management process $50 \%$ of the respondents believe that there are no attempts to influence the results during the decision processes, to serve their own interests, aiming at the improvement and continuity of the business, related of adding value, while the other $50 \%$ believe that there are attempts to influence the outcomes of decision processes, to serve their own interests, and that is done through the strategic planning process.

The strengths of portfolio management to aid decision-making are related to strategic planning and efficiency. As for the improvements pointed out, they are related to the maturity of strategic planning, to achieve the strategic objectives of the organisation.

It was verified by $55 \%$ of the interviewees that the financial method was the most used in the company for decision-making, using financial indices (example, net present value and payback). The favorable side of the financial method for decision-making is the assessment of return on investment. It can impact the improvement and continuity of the business, leaving important projects aside, such as: structuring projects, projects that aim at improving the perception of customers, amongst others.

It was detected that the use of criteria directly assists in decision-making, through targeting well-defined strategic objectives. In this research we noticed an increase in some criteria that should also be taken into account within the organisation: mitigation of operational risks, business intelligence, business diversification, audit points and quality.

Regarding the generalisation of this research, based on Yin (2005), there are four types of generalisation from interpretative case studies: the development of concepts, the generation of theoretical value, the design of specific implications and the contribution of "insights". Walsham (1995) complements that instead of predictions it is possible to use generalisations as tendencies, justifying this research and verifying a tendency of portfolio management to influence decision-making. For the implication of the research provided a good description of a "mechanism" through a single case study that has been investigated and may prove useful for a related view in other organisations and contexts. It is paramount to emphasise that the results of this research cannot be treated in 
a generalised way, due to the methodological procedure adopted. However, the results obtained may be considerations, suggestions and options based on the experiences of a particular group that can be discussed or adopted by other organisations and professionals in different areas, provided they have worked with the portfolio management process.

These results can be used in future studies related to portfolio management and decision-making, mainly in quantitative works, for the confirmation or even the refutation of the findings of this research. For, although there are several studies that evaluate portfolio management and strategic management directly, there is a lack of work on the direct relationship between portfolio management and the literature of decision-making, which makes the information of this research useful for future studies.

\section{Declaration of Conflicting Interests}

The authors declared no potential conflicts of interest with respect to the research, authorship, and/or publication of this article.

\section{Funding}

The authors received no financial support for the research, authorship, and/or publication of this article.

\section{References}

Allison, G.T., Aguero-Martinez, M.O., Aguado-Barrena, O.M., Vargas-Pallares, R., Cordov de Armas, L., \& Garcia, G.L. (1971). Essence of decision: Explaining the Cuban missile crisis. No. 327.5 (729.1) e-libro, Corp.

Archer, N., \& Ghasemzadeh, F. (1999). An integrated framework for project portfolio selection. International Journal of Project Management, 17(4), 207-216. https://doi.org/10.1016/S0263-7863(98)00032-5

Bacharach, S.B., \& Lawler, E.J. (1980). Power and politics in organizations. San Francisco: Jossey-Bass.

Baptestone, R.C., \& Rabechini Jr., R. (2016). Project Portfolio Management: A Bibliometric Analysis Between the 2011 and 2015. 13th CONTECSI International Conference on Information Systems and Technology Management. USP-SP, Brazil. https://doi.org/10.5748/9788599693124-13CONTECSI/PS-3851

Bardhan, I., Bagchi, S., \& Sougstad, R. (2004). Priorizing a portfolio of information technology investment projects. Journal of Management Information Systems, 21(2), 33-60. https://doi.org/10.1080/07421222.2004.11045803

Bazerman, M.H., \& Moore, D. (2009). Judgment in managerial decision-making (7th ed.). Local: John Wiley \& Sons.

Bernoulli, D. (1954). Specimen theoriae novae de mensura sortis (translation by Sommers, L.) Econometrica, 22, 23-36. https://doi.org/10.2307/1909829

Blau, G.E., Pekny, J.F., Varma V.A., \& Bunch, P.R. (2004). Managing a portfolio of interdependent new product candidates in the pharmaceutical industry. Journal of Product Innovation Management, 21(4), 227-245. https://doi.org/10.1111/j.0737-6782.2004.00075.x

Bonner, J.M., Ruekert, R.W., \& Walker, O.C. (2002). Upper management control of new product development projects and project performance. Journal of Product Innovation Management, 19 (3), 233-245.

https://doi.org/10.1111/1540-5885.1930233

Brones, F., Carvalho, M.M., \& Zancul, E.S. (2014). Ecodesign in project management: A missing link for the integration of sustainability in product development? Journal of Cleaner Production, 80(1), 106-118.

https://doi.org/10.1016/j.jclepro.2014.05.088

Butler, R. (2002). Decision-making. In Sorge, A. (Ed.), Organisation (224-251). London: Thomson Learning.

Carvalho, M. De, Lopes, P., \& Marzagão, D. (2013). Gestão de portfólio de projetos: contribuições e tendências da literatura. Gestão Produção, 20(2), 433-453. https://doi.org/10.1590/S0104-530X2013000200013

Chao, R.O., \& Kavadias, S. (2008). A theoretical framework for managing the new product development portfolio: When and how to use strategic buckets. Management Science, 54(5), 907-21. https://doi.org/10.1287/mnsc.1070.0828 
Clemem, R.T., \& Reilly, T. (1996). Making Hard Decisions. An introduction to Decision Analysis (2nd. ed.). Belmont CA: Duxbury Press.

Coldrick, S., Longhurst, P, Ivey, P., \& Hannis, J. (2005). An R\&D options selection model for investment decisions. Technovation, 25(3), 185-193. https://doi.org/10.1016/S0166-4972(03)00099-3

Cooper, R.G., \& Edgett, S.J. (2003). Overcoming the crunch in resources for new product development. Research Technology Management, 46(3), 48-59. https://doi.org/10.1080/08956308.2003.11671566

Cooper, R. G., Edgett, S.J., \& Kleinschmidt, E.J. (1997). Portfolio management in new product development: lessons from the leaders - II. Research Technology Management, 40(5), 43-52.

https://doi.org/10.1080/08956308.1997.11671170

Cooper, R.G., Edgett, S.J., \& Kleinschmidt, E.J. (1999). New product portfolio management: Practices and performance. Journal of Product Innovation Management, 16(4), 333-351. https://doi.org/10.1016/S0737-6782(99)000053

Cooper, R. G., Edgett, S.J., \& Kleinschmidt, E.J. (2000). New problems, new solutions: Making portfolio management more effective. Research Technology Management, 43(2), 18-34.

https://doi.org/10.1080/08956308.2000.11671338

Cooper, R.G., Edgett, S.J., \& Kleinschmidt, E.J. (2001). Portfolio Management for New Product Development: Results of an Industry Practices Study. R\&D Management, 31(4), 361-380. https://doi.org/10.1111/1467-9310.00225

Cooper, R.G., Edgett, S.J., \& Kleinschmidt, E.J. (2002). Optimizing the stage-gate process: What best-practice companies do-II? Research Technology Management, 45(5), 21-28. https://doi.org/10.1080/08956308.2002.11671518

Cooper, R.G., Edgett, S.J., \& Kleinschmidt, E.J. (2004a). Benchmarking best NPD practices I. Research-Technology Management, 47, 31-43. https://doi.org/10.1080/08956308.2004.11671606

Cooper, R.G., Edgett, S.J., \& Kleinschmidt, E.J. (2004b). Benchmarking best NPD practices II. Research-Technology Management, 47, 50-59.

Danesh, D., Ryan, M.J., \& Abbasi, A. (2015). Using Analytic Hierarchy Process as a Decision-Making Tool in Project Portfolio Management, WASET International Journal of Economics and Management Engineering 9(12), 4194-4204.

Dean Jr., \& Sharfman, M. (1996). Does decision process matter? A study of strategic decision-making effectiveness. The Academy of Management Journal, 39(2), 368-396.

Dickinson, M.W., Thornton, A.C., \& Graves, S. (2001). Technology portfolio management: Optimizing interdependent projects over multiple time periods. IEEE Transactions on Engineering Management, 48(4), 518-527. https://doi.org/10.1109/17.969428

Eisenhardt, K.M., \& Zbaracki, M.J. (1992). Strategic decision-making. Strategic Management Journal, 13, 17-37. https://doi.org/10.1002/smj.4250130904

Elbanna, S. (2006). Strategic decision-making: Process perspectives. International Journal of Management Reviews, 8(1), 1-20. https://doi.org/10.1111/j.1468-2370.2006.00118.x

Engwall, M., \& Jerbrant, A. (2003). The resource allocation syndrome: The prime challenge of multi-project management? International Journal of Project Management, 21(6), 403-409. https://doi.org/10.1016/S02637863(02)00113-8

Façanha, S.O., \& Yu, A.S.O. (2011). Abordagem integrada. In Yu, A.S.O. (Coord.), Tomada de decisão nas organizações: uma visão multidisciplinar. São Paulo: Saraiva.

Ginsberg, A. (1988). Measuring and modelling changes in strategy: theoretical foundations and empirical directions. Strategic Management Journal, 9, 559-575. https://doi.org/10.1002/smj.4250090604 
Girotra, K., Terwiesch, C., \& Ulrich, K.T. (2007). Valuing R\&D projects in a portfolio: evidence from the pharmaceutical industry. Management Science, 53, 1452-1466. https://doi.org/10.1287/mnsc.1070.0703

Gleadle, P., Hodgson, D., \& Storey, J. (2012). The ground beneath my feet: projects, project management and the intensified control of R\&D engineers. New Technology, Work and Employment, 27(3), 163-177.

https:// doi.org/10.1111/j.1468-005X.2012.00286.x

Grant, R.M. (2003). Strategic planning in a turbulent environment: evidence from the oil majors. Strategic Management Journal, 24, 491-517. https://doi.org/10.1002/smj.314

Gustafsson, J., \& Salo, A. (2005). Contingent portfolio programming for the management of risky projects. Operations Research, 53(6), 946-956. https://doi.org/10.1287/opre.1050.0225

Haji-Kazemi, S., Andersen, B., \& Krane, H.P. (2013). A review on possible approaches for detecting early warning signs in projects. Project management journal, 44(5), 55-69. https:/ / doi.org/10.1002/pmj.21360

Hall, N.G. (2012). Project management: Recent developments and research opportunities. Journal of Systems Science and Systems Engineering, 21(2), 129-143. https://doi.org/10.1007/s11518-012-5190-5

Hammond, J.S.; Keeney, R.L., \& Raiffa, H. (2004). Decisões Inteligentes: Como avaliar alternativas e tomar a melhor decisão (5ª ed.) (translation by Filardi-Ferreira, M.). Rio de Janeiro: Elsevier.

Hart, S., Jan Hultink, E., \& Tzokas, N. (2003). Industrial companies 'evaluation criteria in new product development gates. Journal of Product Innovation Management, 20(1), 22-36. https:/ / doi.org/10.1111/1540-5885.201003

Hauser, J., Tellis, G.J., \& Griffin, A. (2006). Research on innovation: A review and agenda for Marketing Science. Marketing Science, 25(6), 687-717. https://doi.org/10.1287/mksc.1050.0144

Heising, W. (2012). The integration of ideation and project portfolio management - A key factor for sustainable success. International Journal of Project Management, 30(5), 582-595. https://doi.org/10.1016/j.ijproman.2012.01.014

Hickson, D.J., Butler, R.J., Cray, D., Mallory, G.R., \& Wilson, D.C. (1986). Top decisions: Strategic decision-making in organizations. San Francisco: Jossey-Bass.

Highsmith, J. (2009). Agile Project Management (2nd ed.). Boston, MA: Pearson Education.

Johansson, C., Hicks, B., Larsson, A.C., \& Bertoni, M. (2011). Knowledge maturity as a means to support decision making during product-service systems development projects in the aerospace sector. Project Management Journal, 42(2), 32-50. https://doi.org/10.1002/pmj.20218

Jonas, D., Kock, A., \& Gemünden, H.G. (2013). Predicting project portfolio success by measuring management quality —a longitudinal study. IEEE Transactions on Engineering Management, 60(2), 215-226.

https://doi.org/10.1109/TEM.2012.2200041

Katzy, B., Turgut, E., Holzmann, T., \& Sailer, K. (2013). Innovation intermediaries: a process view on open innovation coordination. Technology Analysis \& Strategic Management, 25(3), 295-309.

https://doi.org/10.1080/09537325.2013.764982

Kester, L., Griffin, A., Hultink, E.J., \& Lauche, K. (2011). Exploring portfolio decision-making processes. Journal of Product Innovation Management, 28(5), 641-661. https://doi.org/10.1111/j.1540-5885.2011.00832.x

Khalili-Damghani, K., \& Tavana, M. (2014). A Comprehensive framework for sustainable project portfolio selection based on structural equation modeling. Journal of Project Management, 45(2), 83-97.

https://doi.org/10.1002/pmj.21404

Killen, C.P., Jugdev, K., Drouin, N., \& Petit, Y. (2012). Advancing project and portfolio management research: Applying strategic management theories. International Journal of Project Management, 30(5), 525-538.

https://doi.org/10.1016/j.ijproman.2011.12.004

Kim, H.J., Kim, H.C., Lee, C.S., Kwon, M., \& Lee, G.S. (2011). Strategic plans for the fusion DEMO program of Korea. Fusion Science and Technology, 60(2), 433-440. https://doi.org/10.13182/FST60-433 
Lin, C.H., \& Hsied, R.J. (2004). A fuzzy decision support for strategic portfolio management. Decision Support Systems, 38(3), 383-398. https://doi.org/10.1016/S0167-9236(03)00118-0

Lint, O., \& Pennings, E. (2001). An option approach to the new product development process: A case study at Philips Electronics. R\&D Management, 31(2), 163-172. https://doi.org/10.1111/1467-9310.00206

Mikkola, J.H. (2001). Portfolio management of R\&D projects: implications for innovation management. Technovation, 21(7), 423-435. https://doi.org/10.1016/S0166-4972(00)00062-6

Miller, C.C., \& Ireland, R.D. (2005). Intuition in strategic decision-making: friend or foe in the fast-paced 21st century. Academy of Management Executive, 19, 19-30.

Mirow, C. (2010). Innovationsbarrieren (1st ed.). Wiesbaden, Germany: Gabler Verlag. https://doi.org/10.1007/978-38349-6100-6

Modica, J.E., Braun, E.M., \& Rabechini Jr., R. (2010). Priorization of a portfolio of projects. In Proceedings of the 8th International Pipeline Conference - IPC2010. Calgary, Alberta, Canada.

Mojsilović, A., Ray, B., Lawrence, R., \& Takriti, S. (2007). A logistic regression framework for information technology outsourcing lifecycle management. Computers \& Operations Research, 34(12), 3609-3627. https://doi.org/10.1016/j.cor.2006.01.018

Morris, P.W., \& Geraldi, J. (2011). Managing the institutional context for projects. Project Management Journal, 42(6), 20-32. https://doi.org/10.1002/pmj.20271

Mostafa, S.P. (2002). Citações Epistemológicas no Campo da Educomunicação. Comunicaşão \& Educação, 8(24), 15-28. https://doi.org/10.11606/issn.2316-9125.v0i24p15-28

Nascimento, P.T.S. (2013). A geração de carteiras ultrapassa a seleção de projetos: deve ser guiada pelas interdependências entre os projetos. Gestão \& Producão, 20(1), 13-22. https://doi.org/10.1590/S0104530X2013000100002

Papadakis, V.M., \& Barwise, P. (1997). What can we tell managers about making strategic decisions? In Papadakis, V.M., \& Barwise, P. (Eds.), Strategic Decisions (267-287). London: Kluwer. https://doi.org/10.1007/978-1-4615-6195$8 \_17$

Parikh, J.I. (1994). Intuition: The New Frontier of Management. Oxford: Blackwell Business.

Patanakul, P. (2013). Key drivers of effectiveness in managing a group of multiple projects. IEEE Transactions on Engineering Management, 60(1), 4-17. https://doi.org/10.1109/TEM.2012.2199993

Pennings, J.M. (1985). Introduction: on the nature and theory of strategic decisions. In Pennings, J.M. (Ed.), Organisation Strategy and Change (1-34). San Francisco: Jossey-Bass.

Pettigrew, A.M. (1973). The politics of organizational decision-making. London: Tavistock. https://doi.org/10.1002/smj.4250130903

Pettigrew, A.M. (1992). The character and significance of strategy process research. Strategic Management Journal, 13, 5-16.

Pfeffer, J. (1981). Power in organizations. Marshfield, MA: Pitman.

Rijke, J., van Herk, S., Zevenbergen, C., Ashley, R., Hertogh, M., \& ten Heuvelhof, E. (2014). Adaptive programme management through a balanced performance/strategy oriented focus. International Journal of Project Management, 32(7), 1197-1209. https://doi.org/10.1016/j.ijproman.2014.01.003

Rogers, M. J., Gupta, A., \& Maranas, C. D. (2002). Real options based analysis of optimal pharmaceutical research and development portfolios. Industrial \& Engineering Chemistry Research, 41(25), 6607-6620.

https://doi.org/10.1021/ie020385p

Russo, J.E., \& Schoemaker, P.J.H. (2002). Decisões vencedoras: como tomar a melhor decisão, como acertar na primeira tentativa (translation by Melo, H.). Rio de Janeiro: Campus. 
Serra, C.E.M., \& Kunc, M. (2015). Benefits realisation management and its influence on project success and on the execution of business strategies. International Journal of Project Management, 33(1), 53-66.

https://doi.org/10.1016/j.ijproman.2014.03.011

Sethi, R., \& Iqbal, Z. (2008). Stage-gate controls, learning failure, and adverse effect on novel new products. Journal of Marketing, 72(1), 118-134. https://doi.org/10.1509/jmkg.72.1.118

Siddiqi, S.N. (2000). Project valuation and power portfolio management in a competitive market. IEEE Transactions on Power Systems, 15(1), 116-121. https://doi.org/10.1109/59.852109

Silvius, G.A.J., \& Schipper, R.P.J. (2014). Sustainability in project management: A literature review and impact analysis. Social Business, 4(1), 3-96. https:/ / doi.org/10.1362/204440814X13948909253866

Siqueira, L.D., \& Crispim, S.F. (2014). Alinhamento dos projetos de TI aos modelos de negócio das organizações. Gestão \& Produção, 21(3), 621-634. https:// doi.org/10.1590/0104-530X294

Spalek, S. (2014). Does investment in project management pay off? Industrial Management \& Data Systems, 114(5), 832-856. https://doi.org/10.1108/IMDS-10-2013-0447

Teller, J., Unger, B.N., Kock, A., \& Gemünden, H.G. (2012). Formalization of project portfolio management: The moderating role of project portfolio complexity. International Journal of Project Management, 30(5), 596-607. https://doi.org/10.1016/j.ijproman.2012.01.020

Too, E.G., \& Weaver, P. (2014). The management of project management: A conceptual framework for project governance. International Journal of Project Management, 32(8), 1382-1394.

https://doi.org/10.1016/j.ijproman.2013.07.006

Torres Jr., S.A., \& Moura, G.L. (2011). Decisão em administração - uma discussão. In Yu, A.S.O. (Coord.), Tomada de decisão nas organizações: uma visão multidisciplinar. São Paulo: Saraiva.

Unger, B.N., Gemünden, H.G., \& Aubry, M. (2012). The three roles of a project portfolio management office: Their impact on portfolio management execution and success. International Journal of Project Management, 30(5), 608-620. https://doi.org/10.1016/j.ijproman.2012.01.015

Vaughan, F.E. (1989). Varieties of intuitive experience.In Agor, W.H. (Ed.), Intuition in Organisations: Leading and Managing Productively (40-61). London: Sage.

Yaghootkar, K., \& Gil, N. (2012). The effects of schedule-driven project management in multi-project environments. International Journal of Project Management, 30(1), 127-140.

https://doi.org/10.1016/j.ijproman.2011.02.005

Yin, R.K. (2005). Estudo de Caso - Planejamento e Métodos (3 ed.). Porto Alegre: Bookman.

Yin, R.K. (2016). Pesquisa qualitativa do início ao fim (translation by Bueno, D.). Porto Alegre: Ed. Penso.

Young, R., Young, M., Jordan, E., \& O’Connor, P. (2012). Is strategy being implemented through projects? Contrary evidence from a leader in New Public Management. International Journal of Project Management, 30(8), 887-900. https://doi.org/10.1016/j.ijproman.2012.03.003

Verma, D., Mishra, A., \& Sinha, K.K. (2011). The development and application of a process model for R\&D project management in a high tech firm: A field study. Journal of Operations Management, 29(5), 462-476. https://doi.org/10.1016/j.jom.2010.11.010

Walsham, G. (1995). Interpretive case studies in IS research: nature and method. European Journal of Information Systems, 4(2), 74-81. https://doi.org/10.1057/ ejis.1995.9

Wang, J.T., \& Hwang, W.I. (2007). A fuzzy set approach for portfolio selection using a real options valuations model. Omega-International Journal of Management Science, 35(3), 247-257. https://doi.org/10.1016/j.omega.2005.06.002

Wilson, D. (2003). Strategy as decision-making. In Cummings, S., \& Wilson, D. (Eds), Images of Strategy (383-410). Oxford: Blackwell. 
Zeynalzadeh, R., \& Ghajari, A. (2011). A framework for project portfolio selection with risk reduction approach. African Journal of Business Management, 5(26), 10474. https://doi.org/10.5897/AJBM11.075

Journal of Industrial Engineering and Management, 2018 (www.jiem.org)

\section{(c) (1) (8)}

Article's contents are provided on an Attribution-Non Commercial 4.0 Creative commons International License. Readers are allowed to copy, distribute and communicate article's contents, provided the author's and Journal of Industrial Engineering and Management's names are included. It must not be used for commercial purposes. To see the complete license contents, please visit https://creativecommons.org/licenses/by-nc/4.0/. 